\title{
Ribosomal ITS diversity among the European species of the genus Hydnum (Hydnaceae)
}

\author{
by \\ Tine Grebenc ${ }^{1}$, María P. Martín ${ }^{2} \&$ Hojka Kraigher ${ }^{1}$ \\ ${ }^{1}$ Slovenian Forestry Institute, Večna pot 2, SI-1000 Ljubljana, Slovenia. tine.grebenc@gozdis.si; hojka.kraigher@gozdis.si \\ ${ }^{2}$ Departamento de Micología, Real Jardín Botánico, CSIC, Plaza de Murillo 2, E-28014 Madrid, Spain. maripaz@rjb.csic.es
}

\begin{abstract}
Grebenc, T., Martín, M.P. \& Kraigher, H. 2009. Ribosomal ITS diversity in the European species of the genus Hydnum (Hydnaceae). Anales Jard. Bot. Madrid 6651: 121-132.

Several morphological species of the genus Hydnum L. are known to occur in Europe, but little molecular evidence exists to confirm the exact number and delimitation of the species. The present study seeks to investigate the genus Hydnum through sequence analysis of the nuclear ribosomal ITS regions and through morphological studies. The DNA sequences phylogenetic analysis revealed high diversity among the ITS region sequences in $H$. repandum (two clades) and $H$. rufescens (six clades) while the specimens of $\mathrm{H}$. albidum, $\mathrm{H}$. umbilicatum and $H$. ellipsosporum formed one and clearly separated clade per morphological species. Phylogenetic distances among the recognised species and the obtained morphologically unsupported clades are comparable and support the idea of several new, yet undescribed species. The intraspecific variability in the sequence data among phylogenetic species is generally low. Detailed morphological analysis of putative informative morphological characteristics could not support any of the observed non-monophyletic DNA-sequences clades within $H$. repandum or $\mathrm{H}$. rufescens, and the proper use of names is not yet clear. Similar intraspecific variation has also been observed in many other ectomycorrhizal genera and could be explained by intensive speciation within variable groups under the influence of various factors (niche effect, ectomycorrhizal partner selection).
\end{abstract}

Keywords: Hydnum repandum, $H$. rufescens, DNA-sequences phylogenetic relationships, morphological traits, nrDNA, intraspecific variability.

\section{Introduction}

Members of the family Hydnaceae Chevallier (1826) are primarily identified by the presence of posi-

\section{Resumen}

Grebenc, T., Martín, M.P. \& Kraigher, H. 2009. Diversidad de las secuencias ITS del ADN ribosómico nuclear en las especies del género Hydnum (Hydnaceae) en Europa. Anales Jard. Bot. Madrid 66S1: 121-132 (en inglés).

En Europa, sobre la base de la morfología se han identificado distintas especies en el género Hydnum L.; sin embargo, no se tenían datos moleculares para confirmar el número exacto de táxones y las relaciones entre los mismos. Este trabajo se basa en los análisis filogenéticos de las secuencias ITS del nrDNA, que se comparan con los estudios morfológicos y los análisis estadísticos. Los análisis filogenéticos revelan una alta diversidad en las secuencias de las regions ITS en $H$. repandum (dos clados) y en $H$. rufescens (seis clados), mientras que las muestras de $H$. albidum, $H$. umbilicatum e $H$. ellipsosporum se agrupan en clados únicos, que coinciden con especies tradicionales basadas en caracteres morfológicos. Los análisis morfológicos y filogenéticos son similares y apoyan la idea de que en este género existen todavía un número de especies no descritas. En las posibles especies filogenéticas, la variabilidad intraespecífica de las secuencias es baja. Por otro lado, el resultado del detallado análisis morfológico no apoya ninguno de los clados de $H$. repandum o $H$. rufescens, por lo que todavía no queda claro el táxon al que designan estos nombres. Una variabilidad intraespecífica similar se ha observado en otros géneros de hongos ectomicorrícicos y podría explicarse por especiación intensiva bajo la influencia de diversos factores (efecto de nicho, selección del hospedante ectomicorrícico).

Palabras clave: Hydnum repandum, $H$. rufescens, relaciones filogenéticas, caracteres morfológicos, ADN ribosómico nuclear, variabilidad intraespecífica.

tive geotropic spines, ranging from small granular warts to clear individual spines (Ainsworth \& al., 1973). Recent literature cites six valid genera in the family. To our knowledge, five of them were never included 
in any molecular analyses: Corallofungus Kobayasi, Dentinum Gray, Gloeomucro R.H. Petersen, Nigrobydnum Ryvarden, and Phaeoradulum Pat. (Kirk \& al. 2001); while Hydnum as the type genus, was the only genus represented in phylogenetic studies. At higher taxonomic rank Hydnum was placed in Cantharellales first by Kreisel (1969) and later confirmed with molecular data by Pine \& al. (1999) and subsequent papers.

In European taxonomic reviews and determination books the following species and varieties/forms have been mentioned in the genus: Hydnum albidum Peck, $H$. repandum L.:Fr. and H. rufescens Pers. (Maas Geesteranus, 1975; Jülich, 1984; Courtecuisse \& Duhem, 1995), H. repandum var. rufescens (Fr.) Barla and $H$. repandum $\mathrm{f}$. rufescens (Pers.) Nikol. (synonym of H. rufescens Pers.) (Marchand, 1973; Cetto, 1976; Gerhardt, 1997). In Slovenia two more taxa have been cited: H. umbilicatum Peck (Petkovšek \& Vrščaj, 1998) [the species generally known from North America (Hall \& Stuntz, 1971) and Asia (Maas Geesteranus, 1971)] and H. repandum f. amarum Vrščaj (Stropnik \& al., 1988); however, the second taxon was never published with a comprehensive description, thus according to Art. 36.1, CABI Bioscience Databases (Kirk \& al., 2003) the name $H$. repandum $\mathrm{f}$. amarum Vrščaj is treated as nom. inval.

Hydnum rufescens and $H$. repandum are distributed over an exceptionally wide area and are even recognised in the Far East (Asia) although several synonyms from different areas and for local populations were published and many local names were conspecific with European species (Maas Geesteranus, 1971). Hydnum elatum Massee and two more unnamed Hydnum species were recognised for Asia and Australia in addition to $H$. umbilicatum (Maas Geesteranus, 1971). The latter was described in North America by Peck (1902). Despite it was commonly found on several continents (Hall \& Stuntz, 1971 ) its presence in Europe was only confirmed for Finland (Huhtinen \& Ruotsalainen, 2006).

Clear delimitation of species cited in Europe is not always easy. Morphological characters can vary with the developmental stage of pileus and environmental conditions during the growth period (Hall \& Stuntz, 1971; Maas Geesteranus, 1975). Spore size and shape can well separate $H$. albidum and $H$. ellipsosporum from the others (Ostrow \& Beenken, 2004) while taxonomical position of $H$. rufescens within the genus is confusing, not only after classical identification but also after molecular data have become available. Molecular identification of $H$. repandum and $H$. rufescens ectomycorrhizae on Norway spruce showed distinct restriction patterns of amplified ITS region in genomic
rDNA. Additionaly the variability of the restriction pattern within $H$. rufescens was observed after digestion of the amplified PCR product with Hinfl endonuclease. The observed additional differences indicate possible variability of collections from different sites (Agerer \& al., 1996). Ostrow \& Beenken (2004) found a good correlation for selected morphological and molecular characters for four European species with only few samples sequenced for each species. They reported no sequence diversity within $H$. rufescens, although only for $H$. repandum and $H$. ellipsosporum was the absence of any such intraspecific variability clearly stated.

Comparison of rDNA ITS sequences is a valuable tool in phylogenetic studies, and to provide more accurate species delimitation (Taylor \& al., 2000). Currently there is a poor overlap between morphological and molecular species concept based on the variability of the rDNA ITS sequences in studied Hydnum collections. To support the results obtained at the molecular level, selected morphological characters indicative of taxonomic affiliation in the genus Hydnum were measured and correlated to the clades retrieved in the DNA-sequences phylogenetic analyses. Multivariate statistics were employed for these analyses.

\section{Materials and methods}

DNA analyses were undertaken in the laboratories in Slovenia (SFI) and in Spain (RJB). The different protocols were standardized at both sites, such that the final results obtained from the same sample were equal. Thin layer cromatography (TLC) analysis was carried out in RJB in Spain.

\section{Fungal material}

Specimens from the genus Hydnum included in the study (Table 1) were either collected from various localities in the years 1999-2002 and stored in the herbarium at Slovenian Forestry Institute (LJU) or obtained from herbarium MA-Fungi (Madrid, Spain). We have tried to locate the type or representative material for European species in different institutional herbaria (UPS, MSB, and PC; Holmgren \& al., 1998). However, according to the curators, the material either does not exist or was not possible to locate. Even though H. umbilicatum has been cited in Slovenia, no reference material was available from the area; the two collections included in the study were kindly sent by Lorelei L. Norvell from the Pacific Northwest Mycology Service.

Specimens with fully developed basidiomata and spores were used for examination of macro- and mi- 
croscopic morphological characters. Fifty spores per basidiomata were measures to calculate an average and extreme values for length, width, and spore volume (Ostrow \& Beenken, 2004) and to assess several other potential informative characters (cap colour, stem diameter and position, cap diameter, spine position, pigmented content, and potential ectomycorrhizal partners on the collection site). Nomenclature followed the morphological species concepts of Maas Geesteranus (1975) (H. repandum and H. rufescens), Focht (1996) and Ostrow \& Beenken (2004) for H. albidum, and Harrison \& Grund (1987) for H. umbilicatum, the only non-European species included in the study.

\section{Molecular methods}

DNA extraction: Twenty milligrams of the hymenium from fresh or dried material were used for the DNA extraction following standard protocols after Whiting \& al. (1997) or using 2\% CTAB (Rogers \& Bendlich, 1985; Doyle \& Doyle, 1990). From older herbarium material DNA was extracted by E.Z.N.A. Fungi DNA Miniprep Kit (Omega Biotek) as described in Martín \& García-Figueres (1999). For both methods DNA was re-suspended in pre-warmed, sterile milli-Q water to the approximate final concentration $100 \mathrm{ng} / \mathrm{ml}$.

PCR amplification: Primers ITS1F (Gardes \& Bruns, 1993) and ITS4 (White \& al., 1990) or ITS4b (Gardes \& Bruns, 1993) were used for PCR amplification of the ITS region, including 5.8 S rDNA. Amplification reactions were obtained using two methods: a) standard procedure described in White \& al. (1990) in a total reaction volume of $40 \mu \mathrm{l}$ with AmplyTaq polymerase (Perkin Elmer) and/or b) individual reactions in a final volume of $25 \mu \mathrm{l}$ with Ready-To-Go PCR Beads (GE Healthcare Life Sciences) as mentioned in Winka \& al. (1998). The PCR reactions were performed after Kraigher \& al. (1995) in a PE 9700 DNA thermocycler with an annealing temperature $55^{\circ} \mathrm{C}$. Negative controls, lacking fungal DNA, were run for each experiment to check for any contamination of the reagents. Amplified DNA was separated and analysed as described in Grebenc \& al., 2000.

Sequencing and cloning: Prior to sequencing, the amplification products were cleaned using the E.Z.N.A. Clean kit. When only weak PCR products were obtained the products were cleaned from the gel using QIAquick Gel (QIAGEN Inc.), cloned with pGEM®-T Easy Vector Systems (Promega), and purified with QIAPrep Spin Mini prep. Three clones were selected for sequencing with vector specific primers T7 and SP6 (QIAGEN Inc.). Sequence Navi- gator Software (Applied Biosystems) was used to identify the consensus sequence from the two strands of each isolate. When the sequences obtained from the cloned products were identical, only one sequence was included in the alignment. The sequences were submitted to EMBL database with the accession numbers indicated in Table 1.

DNA-sequences pbylogenetic analyses: Se-Al v2.0a11 software (http://tree.bio.ed.ac.uk/software/ seal/) for multiple sequences was used to search for the best alignment of new sequences, and sequences from the genus Hydnum already deposited in GenBank or UNITE databases [H. albidum (ALB, AY817135); H. albomagnum (ALM, DQ218305); H. ellipsosporum (ELL, AY917139); H. repandum (REP1, AJ889978; REP2, AJ889949; REP3, AY817136; REP4, DQ218306; REP5 DQ367902; REP6, UDB000025; REP7, UDB000096; REP8, UDB001479); H. rufescens (RUF1, AY817137; RUF2, DQ658890; RUF3, AM087246; RUF4, UDB001465; RUF5, UDB002423); H. umbilicatum DQ367903].

Where ambiguities in the alignment occurred, the alignment chosen was the one generating the fewest potentially informative characters. Alignment gaps were marked "-", unresolved nucleotides and unknown sequences were indicated with " $N$ ". The alignment was analysed using the programmes PAUP *Version 4.0b10 for Macintosh (Swofford, 2002) and MrBAYES 3.0 (Huelsenbeck \& Ronquist, 2001). As an outgroup for the DNA-sequences phylogenetic analysis, we have selected Sistotrema muscicola (Pers.) S. Lundell isolate KHL11721 (AJ606040), and Sistotrema alboluteum (Bourdot \& Galzin) Bondartsev \& Singer isolate TAA180259 (AJ606042), both ectomycorrhizal and closely related to the genus Hydnum (Moncalvo \& al., 2006; De Marino \& al., 2008).

A first maximum parsimony analysis (MP) was inferred using the heuristic search option of the 100 most parsimonious trees in PAUP*4.0b10. Gaps were treated as missing data. Branch lengths equal to zero were collapsed to polytomies. Nonparametric bootstrap support (Felsenstein, 1985) for each clade was tested based on 10000 replicates, using the fast-step option. The consistency index, CI (Kluge \& Farris, 1969), retention index, RI (Farris, 1989), and rescaled consistency index, RC (Farris, 1989) were obtained.

A second analysis was carried out using a Bayesian approach (Huelsenbeck \& al., 2000; Larget \& Simon, 1999). Posterior probabilities were approximated by sampling trees using a Markov Chain Monte Carlo (MCMC) method. The posterior probabilities of each branch were calculated by frequency of trees that were visited during the course of the MCMC analysis. 





The analysis was performed assuming the general time reverse model (Rodriguez \& al., 1990) including estimation of invariant sites and assuming a discrete gamma distribution with six categories $(\mathrm{GTG}+\mathrm{I}+\mathrm{G})$. No molecular clock was assumed. A run with 10000000 generations starting with a random tree and employing 12 simultaneous chains was executed. Every $100^{\text {th }}$ tree was saved into a file of total of 100000 trees. We plotted the log-likelihood scores of sample points against generation time using TRACER 1.0 (http://evolve.zoo.ac.uk/software.html?i=tracer) and determined that stationarity was achieved when the log-likelihood values of the sample points reached a stable equilibrium value (Huelsenbeck \& Ronquist, 2001). The initial 1000 trees were discarded as burning before stationarity was reached. Using the "sumt" command of MrBAYES, majority-rule consensus trees were calculated from 19000 trees sampled after reaching likelihood convergence to calculate the posterior probabilities of the tree nodes. DNA-sequences phylogenetic trees were drawn in TREEVIEW (Page, 1996).

\section{TLC analysis}

Pigment composition was analysed using TLC for selected collections only (Table 1) based on their position in DNA-sequences phylogenetic tree so at least one sample from each clade was included. The acetone extractions from herbarium material were developed (TLC) in the solvent system benzene: ethyl formate: formic acid (10:5:3) in standard Brinkman tanks on $20 \times 20 \mathrm{~cm}$ Merck pre-coated Silica Gel F254 plates (Gill \& Steglich, 1987). Norbadion, badion A, badion $\mathrm{B}$, boviquinon, involutin, gyroporin, telephoric acid, atromentin, variegatic rubin, variegatic acid, xerocomic acid, L-tyrosin, L-DOPA, and ergosterol were used as standard marker pigments. Instead of pure pistillarin we have used a Ramaria cedretorum (Maire) Malençon (MA-Fungi 48074), specimen with positive reaction for pistillarin (Daniëls, 2002). After removal from the tanks, the plates were air dried and examined under visible light and under UV-lamp (245nm and 366nm) following Martín \& SánchezCuixart (1996).

\section{Results}

A total of 32 new ITS nrDNA sequences were generated. The sequences were aligned with 17 ITS nrDNA sequences available from Genbank and UNITE to produce a matrix of 675 unambiguously aligned nucleotide position characters of which 464 were constant, 71 variables are parsimony uninformative, and 140 parsimony informative. The alignment with 52 sequences is available at TreeBASE (http://www. treebase.org/, as SN2182).

Maximum parsimony analysis (MP) under heuristic search gave 12 most parsimonious trees with a length of 345 steps, $\mathrm{CI}=0.6870$, RI $=0.8636$, and $\mathrm{RC}=0.5933$. Figure $1 \mathrm{a}$ shows the strict consensus tree where the bootstrap support values (bs) above $50 \%$ are indicated on the branches and DNA-sequences phylogenetic tree generated by the Bayesian analysis (Fig. 1b). The likelihood parameters of the MP analysis had the following average values ( \pm one standard deviation): likelihood $=-$ base frequencies $\pi(A)=0.2343( \pm 0.00018), \pi(C)=0.193( \pm 0.00017)$, $\pi(G)=0.224( \pm 0.00018), \pi(T)=0.34( \pm 0.00018)$, rate matrix $\mathrm{r}(\mathrm{AC})=2.652( \pm 0.099), \mathrm{r}(\mathrm{AG})=19.289$ $( \pm 0.088), r(\mathrm{AT})=1.729( \pm 0.099), \mathrm{r}(\mathrm{CG})=1.098$ $( \pm 0.001), r(C T)=12.285( \pm 0.089), r(G T)=1.0$ $( \pm 0.0)$, gamma shape parameter alpha $=0.655$ $( \pm 0.0026)$ and the proportion of invariable site $\mathrm{p}($ invar $)=0.255( \pm 0.0029)$. From the Bayesian tree, where the posterior probabilities (pp) were indicated on the branches, only the major, well-supported clades will be discussed in the following.

Both analysis methods applied yielded an identical distribution of terminal clades although the distribution of deeper clades varies slightly. Hydnum albidum forms a single clear clade (AL1, Fig. 1). H. repandum formed two closely related clades (RE1 and RE2, Fig. 1) separated by H. rufescens clade (RU1, Fig. 1). Analysed sporocarps from RU1 show intermixed morphological characteristics between $H$. rufescens and $H$. repandum (Table 2 ). The $H$. rufescens samples were distributed among six more clades (RU1-6, Figs. 1), intemixed with the two sister species H. ellipsosporum and $H$. umbilicatum.

In order to cast additional light on the molecular differences among observed $H$. rufescens and $H$. repandum clades, we applied a TLC chromatography of the pigments in the basidiomata of one collection from each clade (see Table 1). Under visual light no spots of pigment were recognised after the chromatography. Under the illumination with UV (wave length $302 \mathrm{~nm}$ ) spots appeared at Rf: 87.5 (close to ergosterol or L-DOPA), Rf: 73.5, and a longer spot with Rf: 65-59. All samples gave the same pigment composition, though only the intensity of coloration of sporocarps was represented.

Several other potential taxonomic informative characteristics were assessed for samples within each of the clades for possible separation of observed terminal clades in DNA-sequences phylogenetic trees at the morphological level (Table 2). Multiple range tests for 
Strict

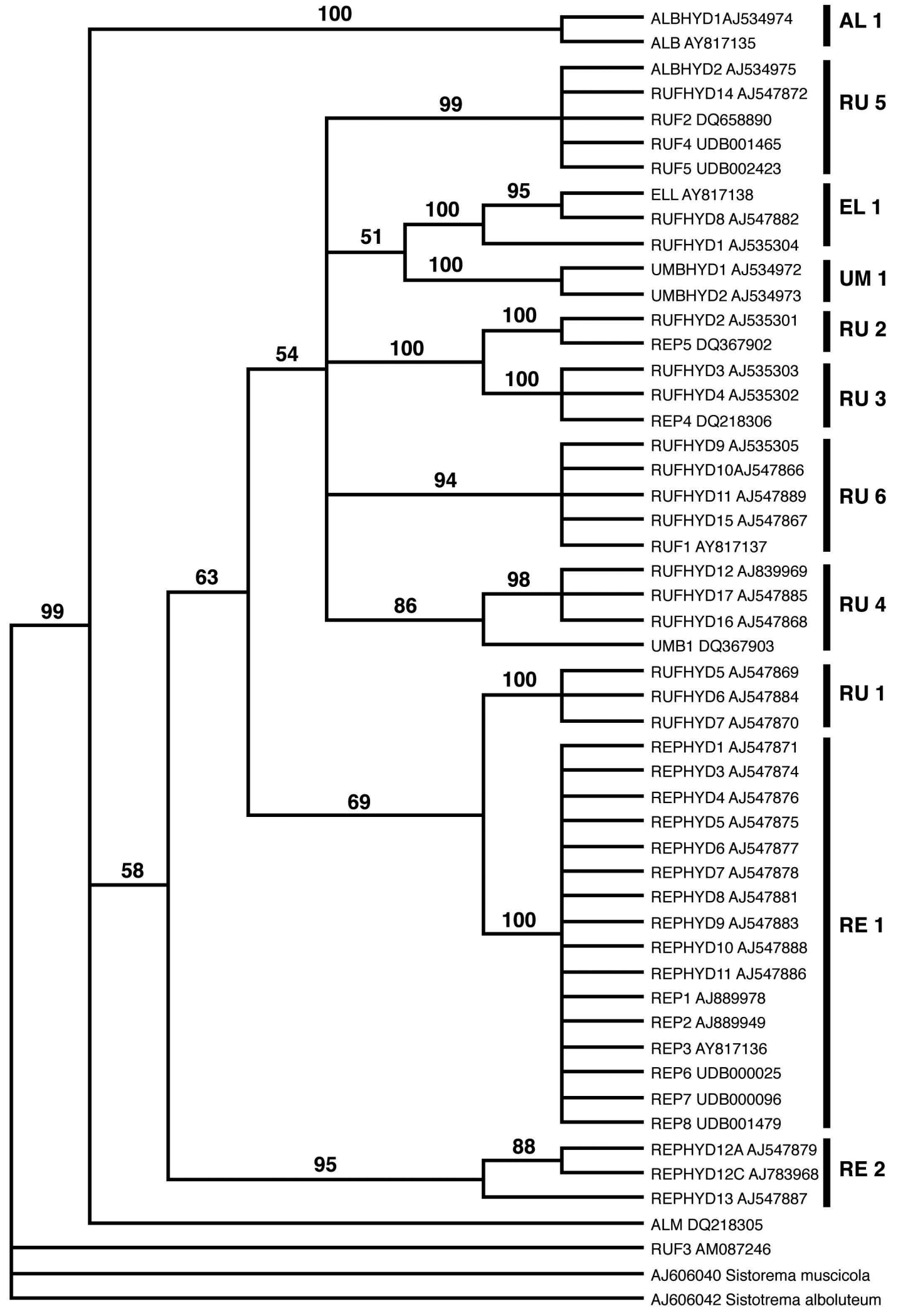

Fig. 1a. DNA-sequences phylogenetic tree for the Hydnum specimens under study. Strict consensus tree with bootstrap values for heuristic search of the 100 most parsimonious trees. DNA-sequences phylogeny clades/morphological species: RU, $H$. rufescens; $\mathrm{RE}, H$. repandum; UM, H. umbilicatum; EL, H. ellipsosporum; AL, H. albidum and ALM, $H$. albomagnum. OTUs names using codes in Tables 1 and 2, followed by the Accession Number from the GenBank or UNITE databases. 


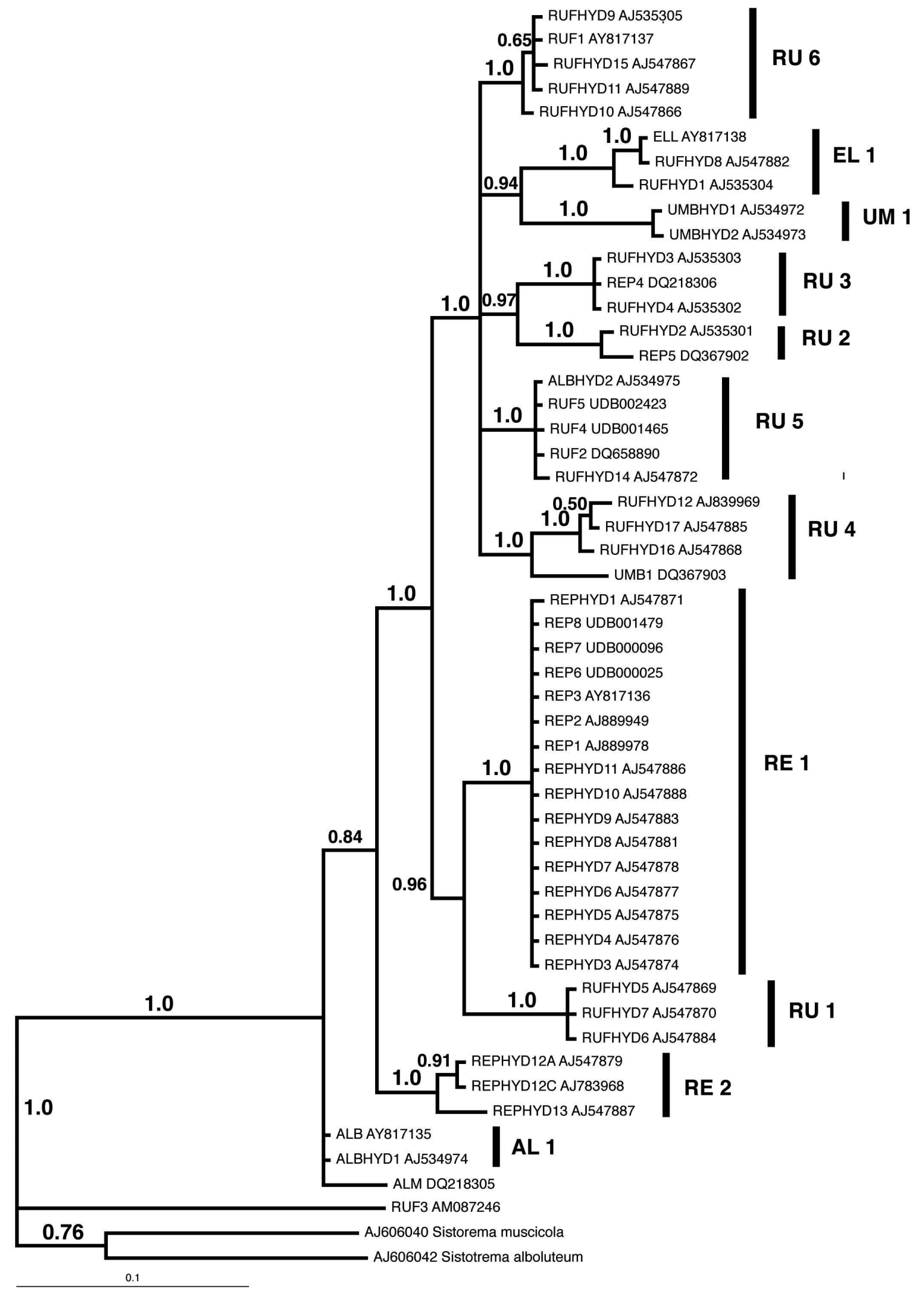

Fig. 1b. DNA-sequences Bayesian phylogenetic tree for the Hydnum specimens under study, with posterior probabilities. DNAsequences phylogeny clades/morphological species: RU , H. rufescens; RE, H. repandum; UM, H. umbilicatum; EL, H. ellipsosporum; $\mathrm{AL}, H$. albidum and ALM, H. albomagnum. OTUs names using codes in Tables 1 and 2, followed by the Accession Number from the GenBank or UNITE databases. 
spore size and volume clearly separated $H$. albidum, $H$. umbilicatum, and $H$. ellipsosporum from $H$. repandum and $H$. rufescens clades, while clades within the latter two morphological species could not be clearly separated, except based on cap colour. We have observed no significant statistical difference between characters within either $H$. repandum or $H$. rufescens clades.

\section{Discussion}

The last comprehensive revision of the family Hydnaceae was published by Maas Geesteranus (1975) based on morphological characteristics of basidiomata and spores. Unequivocally defined taxa are a prerequisite for a comprehensive ecological, physiological, or molecular analysis of a taxon. The aim of this study was: to support the established taxa as recognised after the morphological concept of the species within the European Hydnum species, employing molecular tools, and to clarify the observed molecular differences in the previous study (Agerer $\&$ al., 1996). The value of the presented results would be greater if type material existed and was available at least for $H$. repandum and $H$. rufescens.

The basidiomata included in the study were primarily identified based on morphological characteristics. Spore size and shape can be a good criterion to separate Hydnum albidum, H. ellipsosporum (Ostrow \& Beenken, 2004), and H. umbilicatum (Hall \& Stuntz, 1971) from the rest of Hydnum species from Europe. Huhtinen \& Ruotsalainen (2006) examined the material from Finland and were able to separate all together three taxa within "H. rufescens" specimen: H. ellipsosporum, $H$. umbilicatum and $H$. rufescens s. str. with at least two separate populations in the latter species based on spore shape. However, the data from several identification books/keys (Maas Geesteranus, 1975; Jülich, 1984; Courtecuisse \& Duham, 1995; Ostrow \& Beenken, 2004), as well as the results of the present study indicate that spores of $H$. rufescens and $H$. repandum do not differ significantly in size or shape. The basidiome size, position of the stipe, distribution of the spines, and shape and colour of the basidiome were relatively reliable morphological criteria to distinguish these two morphological species without the need to employ molecular tools, yet our results indicate much higher diversity within these two species. An umbilicate pileus, otherwise typical for $H$. umbilicatum (Hall \& Stuntz, 1971), was observed for some collections of $H$. rufescens from Europe but observed morphological characteristics do not indicate the presence of $H$. umbilicatum in Europe since the spore size is within the range of $H$. rufescens and the umbilicate pilei were distributed among different DNA-sequences phylogenetic clades obtained (data not shown). The exception is a collection from Finland which was microscopically identified as $H$. umbilicatum but not anaysed at DNA level (Huhtinen \& Ruotsalainen, 2006). In specimens of $H$. umbilicatum collected in North America (Harrison \& Grund, 1987) or Asia (Maas Geesteranus, 1971), the spores are larger than for other species and form a unique clade within the DNA-sequences phylogenetic tree, similary distant from several $H$. rufescens clades and $H$. ellipsosporum. Solely using morphological criteria a misidentification of $H$. rufescens with $H$. umbilicatum would only be possible for samples with extremely large spores which might explain the use of the name "umbilicatum" in some European literature.

Hydnum ellipsosporum was first described only recently, based on many collections from Germany (Ostrow \& Beenken, 2004). The distribution of this species seems to be broader since two collections analysed in our study were from Spain (RUFHYD8) and Slovenia (RUFHYD1), at both locations collected from sites dominated by broadleaved trees, which is not common for other Hydnum collections. The species was also confirmed from various locations in Finland. After the DNA-sequences phylogenetic analyses, we confirmed Ostrow \& Beenken's well supported molecular and morphological separation of the species from other European species of Hydnum.

Based on DNA-sequences, the phylogenetic separation within $H$. repandum and $H$. rufescens indicates higher DNA-sequences variability than that observed solely at the morphological level. Within DNAsequences phylogenetic trees based on ITS1, 5.8S and ITS2 sequences nrDNA, $H$. repandum specimens formed two non-monophyletic but well supported clades (RE1 and RE2) after both maximum parsimony and Bayesian analysis. The only morphological criterion to separate these two clades is the size of pileus, which appeared smaller for collections distributed in clade RE2. Additionally, clade RU1 (samples identified as $H$. rufescens, but with mixed morphological characteristics of $H$. rufescens and $H$. repandum; see Table 2) appeared as neighbour clade. In this case, despite being uncommon in fungi (Spiers and Hopcroft, 1994), hybridisation cannot be excluded. The resolution obtained from the ITS region was not enough to distinguish $H$. repandum and $H$. repandum $\mathrm{f}$. amarum (HYDREP1), a locally recognised form reported to be non-edible due to its bitter taste at all developmental stages of the fruitbody (Stropnik \& al., 1988; Petkovšek \& Vrščaj, 1998). A somewhat bitter taste of some basidiomata of $H$. repandum has been 


\begin{tabular}{|c|c|c|c|c|c|c|c|c|c|c|c|}
\hline 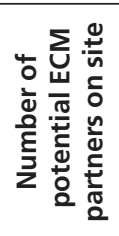 & - & $\sim$ & $\sim$ & $\sim$ & - & - & - & $\sim$ & $\stackrel{m}{+}$ & $\sim$ & $\stackrel{+}{+}$ \\
\hline$\frac{\mathscr{u}}{\overline{0}}$ & 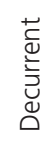 & 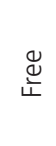 & $\underset{\stackrel{\Perp}{\Psi}}{\stackrel{\Perp}{\Psi}}$ & 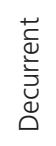 & 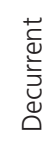 & $\frac{\Phi}{\frac{\Perp}{L}}$ & 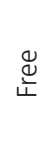 & 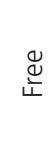 & 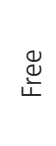 & $\underset{\frac{\Phi}{4}}{\Phi}$ & 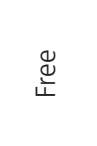 \\
\hline 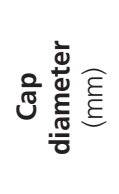 & 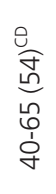 & $\begin{array}{l}\stackrel{\infty}{a} \\
\stackrel{\infty}{d} \\
\stackrel{n}{n} \\
\stackrel{n}{n}\end{array}$ & 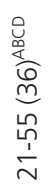 & $\begin{array}{l}\frac{0}{0} \\
\frac{0}{2} \\
\text { on } \\
\stackrel{n}{n}\end{array}$ & 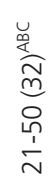 & 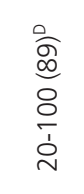 & $\begin{array}{l}\stackrel{a}{\tilde{m}} \\
\stackrel{d}{d} \\
\stackrel{m}{m} \\
o \\
0\end{array}$ & 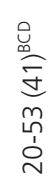 & $\begin{array}{l}\stackrel{a}{d} \\
\underset{d}{\pi} \\
\underset{1}{\infty} \\
\infty\end{array}$ & 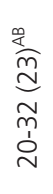 & $\begin{array}{l}\frac{\infty}{0} \\
\hat{m} \\
0 \\
o \\
0 \\
\infty \\
\infty\end{array}$ \\
\hline 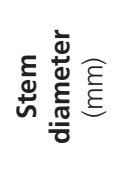 & $\begin{array}{l}0 \\
\underline{p} \\
\omega \infty \\
\infty \\
\infty \\
m \\
\vdots \\
b\end{array}$ & $\begin{array}{l}\frac{m}{d n} \\
n \\
m \\
0 \\
m \\
m\end{array}$ & 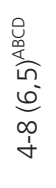 & $\begin{array}{l}0 \\
1 n \\
\sigma \\
\stackrel{2}{n} \\
\text { ก่ }\end{array}$ & 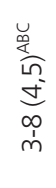 & $\begin{array}{l}\stackrel{e}{\tilde{m}} \\
\stackrel{\omega}{n} \\
\hat{m} \\
\dot{m}\end{array}$ & 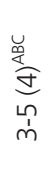 & $\begin{array}{l}\stackrel{0}{0} \\
\stackrel{\infty}{\sigma} \\
\text { ம் }\end{array}$ & 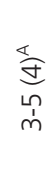 & 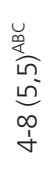 & 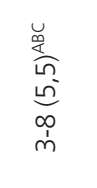 \\
\hline 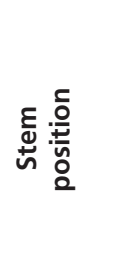 & 焉 & 宽 & 胥 & 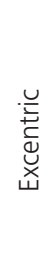 & 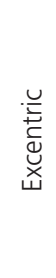 & 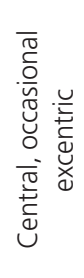 & 苞 & 莣 & 苞 & 胥 & 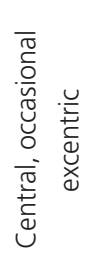 \\
\hline 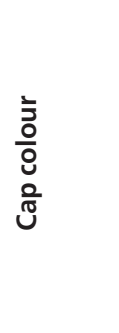 & 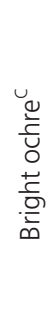 & 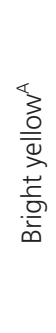 & 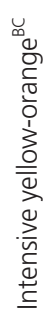 & 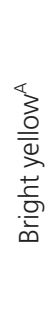 & 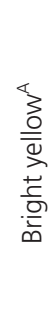 & 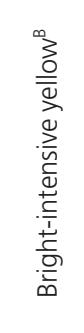 & 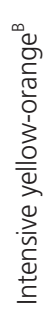 & 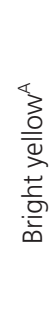 & 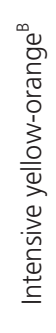 & 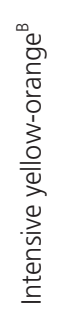 & 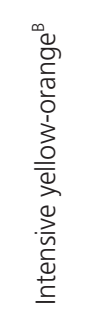 \\
\hline 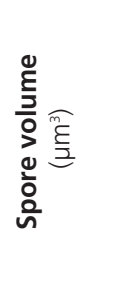 & 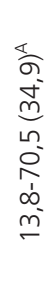 & 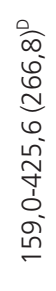 & 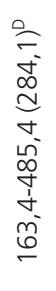 & 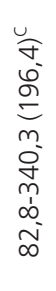 & 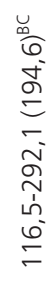 & 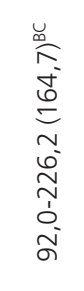 & 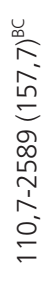 & 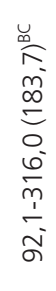 & 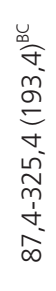 & 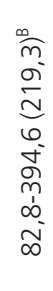 & 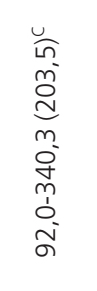 \\
\hline 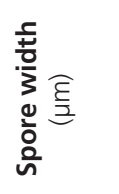 & 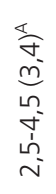 & 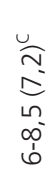 & $\begin{array}{l}\text { Un } \\
\stackrel{-}{0} \\
0 \\
\frac{0}{1}\end{array}$ & 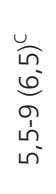 & 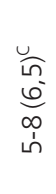 & 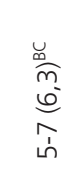 & 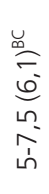 & 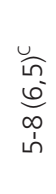 & $\begin{array}{l}\widehat{U} \\
0 \\
0 \\
0 \\
o \\
\omega \\
\omega\end{array}$ & $\begin{array}{l}\infty \\
\infty \\
0 \\
0 \\
0 \\
\dot{1} \\
\omega^{\prime}\end{array}$ & 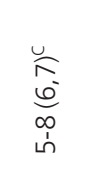 \\
\hline 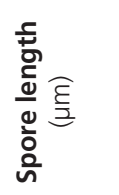 & \begin{tabular}{l}
$\frac{1}{0}$ \\
0 \\
\multirow{J}{*}{} \\
0 \\
$\dot{J}$
\end{tabular} & 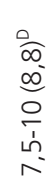 & $\begin{array}{l}0 \\
\infty \\
\infty \\
0 \\
0 \\
\dot{0}\end{array}$ & 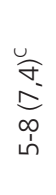 & 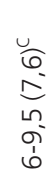 & 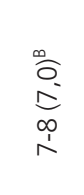 & 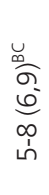 & $\begin{array}{l}\stackrel{0}{\check{c}} \\
\stackrel{0}{a} \\
\dot{0}\end{array}$ & $\begin{array}{l}\text { Un } \\
\text { N } \\
\text { on } \\
\text { ஸे } \\
\text { n' }\end{array}$ & 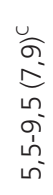 & 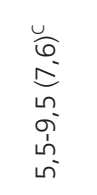 \\
\hline $\begin{array}{l}\frac{\pi}{0} \\
\frac{\pi}{U}\end{array}$ & $\vec{\varangle}$ & $\sum_{J}$ & $\vec{w}$ & $\overline{\breve{\Sigma}}$ & $\underset{\widetilde{u}}{\mathbb{x}}$ & 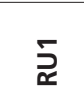 & $\underset{\sim \widetilde{x}}{\mathrm{~s}}$ & 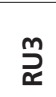 & $\underset{\sim}{\sim}$ & 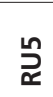 & 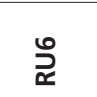 \\
\hline
\end{tabular}


reported by other authors for collections from Asia. A similar taste has also occasionally been noticed in Europe by Jaccottet in 1948 (cit. in Maas Geesteranus, 1971) but it was never proposed to form a separate taxonomical unit. No data is available for constant and uniform occurrence of basidiomata with a bitter taste. This character may be due to the influence of ecological conditions of the site.

Hydnum rufescens, the only species within the genus with previously confirmed intraspecific variability (Agerer \& al., 1996), appeared to be the most variable. The specimens were found to fall into six well supported but non-monophyletic clades after DNAsequences phylogenetic analysis. The DNA-sequences phylogenetic tree distances between each of the neighbouring $H$. rufescens clades and other sister clades (e.g. well established species $H$. umbilicatum and $H$. ellipsosporum) indicate that each of the six $H$. rufescens clades can be recognised and treated as separate species. The morphological information assessed did not correlate well with the molecular results. Rough statistical analysis can only separate group RU3, with generally larger sporocarps but no significant difference in spore size, and no other assessed characteristics could be found for any of the other clades.

The main evolution force for ribosomal region is a concerted evolution which should lead to homogenisation of individual repeats and produce a uniform sequence in all repeats of a given phylogenetic species (Vogler \& DeSalle, 1994). Differences in sequences within one morphological species, as observed in $H$. repandum and $H$. rufescens, may indicate the presence of more than one phylogenetic species (cryptic species) or variation within the species on a molecular level which cannot be explained by the concerted evolution theory. Similar variation and presence of more phylogenetic species was earlier observed and proposed within Rbizopogon roseolus (Martín \& al., 2000), Tricholoma flavovirens (Pers.) S. Lundell. (Horton, 2002), Tuber rufum (Iotti \& al., 2007; Grebenc \& al., in prep), and in other ectomycorrhizal genera (Leccinum, Lactarius, Inocybe, Tricholoma, and Russula) (Kåren \& al., 1997; Horton, 2002). This could be the case in Hydnum rufescens and H. repandum as well. Relatively high abundance of such variability seriously challenges the morphological species concept for these taxa. Several studies demonstrated that DNA-sequences based phylogenetic species recognition and concept were advantageous in mycology and seem likely to become popular among mycologists (Taylor \& al., 2000). It could well be applied in the case of $H$. rufescens, $H$. repandum, yet raising the question about the use of current names for several phylogenetic species.
Despite relatively high genetic distance in the DNA-sequences phylogenetic tree, the geneflow between clades cannot be excluded, but the presence of putative heteroduplex in rDNA was rejected using DGGE analysis of ITS region (Grebenc \& al., 2006).

Based on the high molecular diversity of presumably homogeneous $\mathrm{rDNA}$ region in $H$. rufescens and H. repandum these two species may be in a process of intensive speciation, not correlated to the geographical distances between the different clades obtained. There are several possible triggers which could lead to a possible diversification at the molecular level in $H$. rufescens and H. repandum. Harrington \& Rizzo (1999) reported a high importance of niche in determining the development and maintenance of fungal species which is not necessarily correlated to geographical distances. H. rufescens and H. repandum are common species in Europe growing next to one or more different ectomycorrhizal partners (Table 1) which could lead to a possible diversification at the molecular level, as observed in the H. ellipsosporum samples analysed. Other ecological variables not quantified in the present study, for example soil and other environmental parameters, possible niche specialist character of the species (Giraud \& al., 2008), or ectomycorrhiza characteristics and partners, mating types, etc., should be evaluated to explain the variability at the molecular level.

\section{Acknowledgements}

The study was supported through the research programme P40107, young researchers' scheme and project Z4-7578, financed by the Ministry of Education, Science and Sports of the Republic of Slovenia, the Bilateral Project Spain-Slovenia (2000SI003), the BIOD-IBERIA projects A9 and A64, and Ministerio de Educación y Ciencia (CGL2006-12732-C02-01/BOS). Special thanks go to Lorelei L. Norvell, Pacific Northwest Mycology Service for providing the herbarium material of Hydnum umbilicatum and the North American literature. Thanks to Dr. Miguel Á. García for support during the cloning procedure used in this study.

\section{References}

Agerer, R., Kraigher, H. \& Javornik, B. 1996. Identification of ectomycorrhizae of Hydnum rufescens on Norway spruce and the variability if the ITS region of $\mathrm{H}$. rufescens and $\mathrm{H}$. repandum (Basidiomycetes). Nova Hedwigia 63 (1-2): 183-194.

Ainsworth, G.C., Sparrow, F.K. \& Sussman, A.S. 1973. The fungi. An Advanced Treatise (Volume IV B. A taxonomic review with keys: Basidiomycetes and Lower fungi). Academis Press, NY and London.

Cetto, B. 1976. I funghi dal vero. 2. Arti Grafiche Sa-turnia, Trento. Chevallier, F.F. 1826. Flore Générale des Environs de Paris. Vol. 1. F. Jeune, Paris.

Courtecuisse, R. \& Duhem, B. 1995. Mushrooms \& Toadstools of Britain E Europe (Collin Field Guide). Harpers Publishers, London. 
Daniëls, P.P. 2002. Estudio biosistemático de los Gomphales (Basidiomycota, Fungi) ibéricos. Doctoral thesis Univ. Complutense Madrid. 300 pp.

Di Marino, E., Scattolin, L., Bodensteiner, P. \& Agerer, R. 2008. Sistotrema is a genus with ectomycorrhizal species - confirmation of what sequence studies already suggested. Mycological Progress 7(3): 169-176.

Doyle, J.J. \& Doyle, J.L. 1990. A rapid DNA isolation procedure for small quantities of fresh leaf tissue. Phytochemical Bulletin 19: 11-15.

Farris, J.S. 1989. The retention index and the rescaled consistency index. Cladistics 5: 417-419.

Felsenstein, J. 1985. Confidence limits on phylogenies: an approach using the bootstrap. Evolution 39: 783-791.

Focht, I. 1996. Ključ za glive. $4^{\text {th }}$ edition. Naklada Naprijed, Zagreb.

Fries, E.M. 1821. Systema mycologicum. Vol. 1. Lund.

Gardes, M. \& Bruns, T.D. 1993. ITS primers with enhanced specifity for basidiomycetes - application to the identification of mycorrhizae and rusts. Molecular Ecology 2: 113-118.

Gerhardt, E. 1997. Der grosse BLV-Pilzführer für unterwegs: über 1200 Arten, über 1000 Farbfotos. BLV Verlagsgesellschaft $\mathrm{GmbH}$, München, Wien, Zürich.

Gill, M. \& Steglich, W. 1987. Progress in the chemistry of organic natural products. Edition Springer Verlag, Wien New York.

Giraud, T., Refrégier, G., Le Gac, M., de Vienne, D.M. \& Hood, M.E. 2008. Speciation in fungi (Review). Fungal Genetics and Biology 45: 791-802.

Grebenc, T., Piltaver, A. \& Kraigher, H. 2000. Establishment of the PCR-RFLP library for Basidiomycetes, Ascomycetes and their ectomycorrhizae on Picea abies (L.) Karst. Phyton, Annales rei Botanicae 40(4): 79-82.

Grebenc, T., Al Sayegh-Petkovšek, S., Pokorny, B. \& Kraigher, H. 2006. Detection of point mutations in selected genome regions from sporocarps of heavy metal exposed Hydnum repandum and Clitocybe nebularis as putative indicator species. In: Dolenc Koce, J., Vodnik, D. \& Dermastia, M. (eds.), 4th Slovenian Symposium on Plant Biology with International Participation, Ljubljana, September 12-15, 2006. The Slovenian Society of Plant Physiology, Ljubljana. pp. 152-153.

Hall, D. \& Stuntz, D.E. 1971. Pileate Hydnaceae of the Puget Sound area. I. White-spored genera: Auriscalpum, Hericium, Dentinum and Phellodon. Mycologia 63: 1099-1128.

Harrington, T.C. \& Rizzo, D.M. 1999. Defining species in the fungi. In: Worrall, J.J (ed.), Structure and Dynamics of Fungal Populations. Kluwer Press. Dordrecht, The Netherlands. pp. 4371.

Harrison, K.A. \& Grund, D.W. 1987. Preliminary keys to the terrestrial stipitate hydnums of North America. Mycotaxon 28(2): 419-426.

Holmgren, P.K. \& N.H. Holmgren. 1998. Index Herbariorum: A global directory of public herbaria and associated staff. New York Botanical Garden's Virtual Herbarium. http:// sweetgum.nybg.org/ih/

Horton, T.R. 2002. Molecular approaches to ectomycorrhizal diversity studies: variation in ITS at a local scale. Plant and Soil 244: 29-39.

Huelsenbeck, J.P. \& Ronquist, F. 2001. MRBAYES: Bayesian inference of phylogenetic trees. Bioinformatics 17(8): 754-755.

Huelsenbeck, J.P., Rannala, B. \& Masly, J.P. 2000. Accommodating phylogenetic uncertainty in evolutionary studies. Science 288 (5475): 2349-2350.

Huhtinen, S. \& Ruotsalainen, J. 2006. Variability of Hydnum rufescens in Finland: three taxa hidden under one name - and one appearance? Karstenia 46: 17-24. www.treebase.org/treebase/ (15.01.2009)
Iotti, M., Amicucci, A., Bonito, G., Bonuso, E., Stocchi, V. \& Zambonelli, A. 2007. Selection of a set of specific primers for the identification of Tuber rufum: a truffle species with high genetic variability. FEMS Microbiology Letters 277(2): 233-231.

Jülich, W. 1984. Kleine Kriptogamenflora. Bd.2. Pilze b. Basidiomyceten Teil 1. Die Nichtblätterpilze, Gallertpilze und Bauchpilze. Gustav Fischer Verlag. Stuttgart. New York.

Kåren, O., Högberg, N., Dahlberg, A., Jonsson, L. \& Nylund, J.E. 1997. Inter- and intraspecific variation in the ITS region of rDNA of ectomycorrhizal fungi in Fennoscandia as detected by endonuclease analysis. New Phytologist 136: 313-325.

Kirk, P.M., Cannon, P.F., David, C.J. \& Stalpers, J.A. (eds.). 2001. Dictionary of fungy. 9th Edition. CABI Bioscience, Oxon, UK.

Kirk, P.M., Cannon, P.F., David, J.C. \& Stalpers, J.A. 2003. www.indexfungorum.org, (last visited on 01st September 2008).

Kluge, A.G. \& Farris, J.S. 1969. Quantitative phyletics and the evolution of anurans. Systematic Zoology 18: 1-32.

Kraigher, H., Javornik, B. \& Agerer, R. 1995. Ectomycorrhizae of Lactarius lignyotus on Norway spruce, characterized by anatomical and molecular tools. Mycorrbiza 5(3): 175-180.

Kreisel, H. 1969. Grundzüge eines natürliches Systems der Pilze. Jena, Germany. Gustav Fischer Verlag/Cramer.

Larget, B. \& D.L. Simon. 1999. Markov chain Monte Carlo algorithms for the Bayesian analysis of phylogenetic trees. Molecular Biology and Evolution 16: 750-759.

Maas Geesteranus, R.A. 1971. Hydnaceous fungi of the Eastern Old World. Verhandelingen der Koninklije Nederlandse Akademie van Wetenschappen, afd. Natuurkunde, Tweede reeks 60(3): 1-176.

Maas Geesteranus, R.A. 1975. Die terrestrischen Stachelpilze Europas (The terrestrial hydnums in Europe). Verhandelingen der Koninklije Nederlandse Akademie van Wetenschappen, afd. Natuurkunde, Tweede reeks 65: 1-127.

Marchand, A. 1973. Champignons du nord et du midi. Les meilleurs comestibile. Société mycologique des Pyrénées Méditerranéennes, Perpignan.

Martín, M.P. \& García-Figueres, F. 1999. Colletotrichum acutatum and C. gloeosporioides cause anthracnose on olives. European Journal of Plant Pathology 105: 733-741.

Martín, M.P. \& Sánchez-Cuixart, A. 1996. Thin layer chromatography patterns of Rhizopogon species and their possible use as a taxonomic criterion. Revista Catalana Micologia 19: 91-98.

Martín, M.P., Kårén, O. \& Nylund, J.-E. 2000. Molecular ecology of hypogeous mycorrhizal fungi: Rhizopogon roseolus (Basidiomycotina). Phyton, Annales rei Botanicae 40(4): 135-141.

Moncalvo, J.-M., Nilsson, R.H., Koster, B., Dunham, S.M., Bernauer, T., Matheny, P.B., Porter, T.M., Margaritescu, S., Weiß, M., Garnica, S., Danell, E., Langer, G., Langer, E., Larsson, E., Larsson, K.-H. \& Vilgalys, R. 2006. The cantharelloid clade: dealing with incongruent gene trees and phylogenetic reconstruction methods. Mycologia 98(6): 937-948.

Ostrow, H. \& Beenken, L. 2004. Hydnum ellipsosporum spec. nov. (Basidiomycetes, Cantharellales) - ein Doppelgänger von Hydnum rufescens Fr. Zeitschrift fuer Mykologie 70(2): 137-156.

Page, R.D.M. 1996. TreeView: An application to display phylogenetic trees on personal computers. Computer Applications in the Biosciences 12(4): 357-358.

Peck, C.H. 1902. Hydnum umbilicatum Peck. Bulletin of the New York State Museum 54: 953.

Petkovšek, V. \& Vrščaj, D. 1998. Hydnum spp. In: Poler, A. (ed.), The list of the fungi from Slovenia. ZGDS, Ljubljana. p. 34.

Pine, E.M. Hibbett, D.S. \& Donoghue, M.J. 1999. Phylogenetic relationships of cantharelloid and clavarioid Homobasidiomycetes based on mitochondrial and nuclear rDNA sequences. Mycologia 91: 944-963. 
Rodríguez, F., Oliver, J.F., Marín, A. \& Medina, J.R. 1990. The general stochastic model of nucleotide substitution. Journal of Theoretical Biology 142: 485-501.

Rogers, S.O. \& Bendlich, A.J. 1985. Extraction of DNA from milligram amounts of fresh, herbarium and mummified plant tisue. Plant Molecular Biology 5: 69-76.

Spiers, A.G. \& Hopcroft, D.H. 1994. Comparative studies of the poplar rust Melanospora medusea, M. larici-populina and their interspecific hybrid M. medusae-populina. Mycological Research 98: 889-903

Stropnik, S., Tratnik, B. \& Seljak, G. 1988. Naše gobje bogastvo (plate 451). Mladinska knjiga, Ljubljana (in Slovene).

Swofford, D.L. 2002. PAUP*. Phylogenetic Analysis Using Parsimony ("and Other Methods). Version 4. Sinauer Associates, Sunderland, Massachusetts.

Taylor, J.W., Jacobson, D.J., Kroken, S., Kasuga, T., Geiser, D.M., Hibbet, D.S. \& Fisher, M.C. 2000. Phylogenetic species recognition and species concepts in fungi. Fungal Genetics and Bio$\log 3$ 31:21-32.
Vogler, A.P. \& DeSalle, R. 1994. Evolution and phylogenetic information content of the ITS-1 region in the tiger beetle Cicindela dorsalis. Molecular Biology and Evolution 11:393-405.

White, T.J., Bruns, T., Lee, S. \& Taylor, J. 1990. Amplification and direct sequencing of fungal ribosomal RNA genes for phylogenetics. In: Innis, M.A., Gelfand, D.H., Sninsky, J.J. \& White, T.J. (eds.), PCR Protocols. A Guide to Methods and Applications. San Diego, Academic Press. pp. 315-322.

Whiting, M.F.J., Carpenter, J.C., Wheeler, Q.D. \& Wheeler, W.C. 1997. The Strepsiptera problem: phylogeny of the holometabolous insect orders inferred from $18 \mathrm{~S}$ and $28 \mathrm{~S}$ ribosomal DNA sequences and morphology. Systematic Biology 46: $1-68$.

Winka, K., Ahlberg, C. \& Eriksson, O.E. 1998. Are there lichenized ostropales? Lichenologist 30(4-5): 455-462.

Received: 20-X-2008

Accepted: 16-II-2009 